and exits are forgotten: Xanthias is rightly sent off at Wasps 843, and then in 899-904 we find him and the two dogs all present although there has been no direction for their entrance.

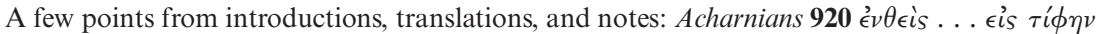

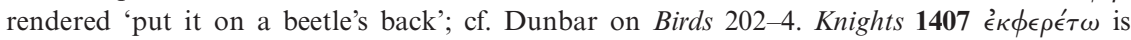
translated 'escort', and the final stage direction has Paphlagon 'marched off' by two slaves; but the

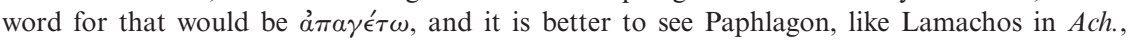
Socrates in Clouds, and in a sense Euripides in Frogs, as suffering a comic death, here

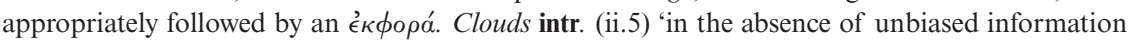
about Socrates . . . we must accept Clouds as a valid expression of what public opinion ... might be expected to believe about him, in the Athens of 423-c. 416': it is perhaps rash to assert this without qualification (were not comic spectators conditioned to expect exaggeration and caricature?), but we may note that even Plato chooses, in the Apology, to present Socrates' actual accusers not as mendacious but as ignorant and muddled, and no doubt many ordinary Athenians had been at least as ignorant and muddled about him two decades before his trial. $\mathbf{6 0 9}$ H. attractively suggests (developing a hint of Dover's) that zai $\rho \epsilon \nu$ here is 'a jab at Cleon' who was apparently (cf. $\Sigma$ and Eupolis fr. 331) the first Athenian to begin an official dispatch with this

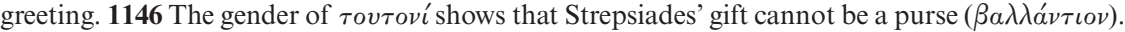
Wasps 753 H.'s rendering 'what I yearn for is over there' presumably implies, surely rightly (though as usual there is no stage direction), that Philokleon here points (repeatedly and frantically) in the direction representing the way to the courts (i.e. towards the eisodos opposite to that by which the chorus entered). 1418 'Assault' is far too weak to translate $v \beta \rho \iota s$, a crime for which the prosecutor might if he chose demand the death penalty; if we must have something that sounds like a modern criminal charge, I would suggest 'aggravated violence'. Peace 1193 Another gender point: $\tau \alpha v \tau \eta{ }^{\prime}$ shows that the object with which the tables are to be cleaned cannot be a

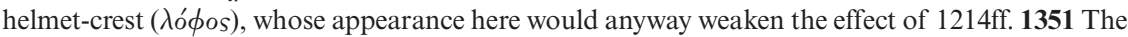

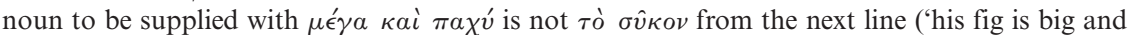
ripe' H.), but $\tau \dot{o} \pi \epsilon$ '́s from the joint evidence of the audience's eyes-for Trygaios, like Dikaiopolis, the Scythian Archer and Blepyros at the ends of three other plays, is ithyphallic (so tentatively but rightly Olson) - and of the phrase $\mu \epsilon^{\prime} \gamma \alpha \kappa a i$ ma $\chi^{\prime}$ itself which, in comedy at least, only ever refers to one thing.

The completion of this edition will be eagerly awaited.

University of Nottingham

ALAN H. SOMMERSTEIN

\title{
GREEK COMIC FRAGMENTS
}

\section{A. M. Belardinelli, O. Imperio, G. Mastromarco, M. Pellegrino, P. Totaro: Tessere. Frammenti della commedia greca: studi e commenti. Pp. 383. Bari: Adriatica Editrice, 1998. Paper, L. 45,000 .}

As the title of this collection indicates, its authors want to present some surviving 'tesserae' out of the grand, but largely destroyed, mosaic of ancient Greek Comedy. The book comprises two sections. First, two 'studi' provide diachronic surveys of certain comic figures: on pp. 9-42, Giuseppe Mastromarco outlines the development of the Cyclops from the Odyssey to his rôle in fifth-century drama (Epicharmus, Euripides, Cratinus, Callias, Aristias) and shows that Polyphemus, while fundamentally remaining the monstrous man-eater, nevertheless shows some 'cultural advancement', acquiring not only remarkable culinary, but also

(c) Oxford University Press, 2000

Downloaded from https:/www.cambridge.org/core. University of Basel Library, on 10 Jul 2017 at 16:48:28, subject to the Cambridge Core terms of use, available at https:/www.cambridge.org/core/terms. https://doi.org/10.1093/cr/50.1.12 
geographical, poetical, and even philosophical lore. The Euripidean Cyclops even seems to develop certain 'aristocratic' traits (e.g. hunting and pederastic inclinations), but M. probably goes too far when he attributes these to the comic Cyclops as well; as far as I can see, there is no evidence in the comic fragments for a Polyphemus loving to hunt or pining for beautiful boys. On pp. 43-130, Olimpia Imperio deals with the comic portrayals of intellectuals, starting with the Homeric $\delta \eta \mu \iota є \epsilon \gamma \sigma i$ and arriving only on p. 51 at the various groups of $\sigma \circ \phi \iota \sigma \tau \alpha \iota$ presented in Aristophanes' Clouds (331-3), whose depiction in Old Comedy she then examines in detail: first, professional seers and oracle-mongers (pp. 54-63); second, physicians (pp. 63-75); third, dithyrambographers (pp. 75-95), where she reaffirms the widely accepted distinction of various phases in the comic poets' reactions against the 'new' dithyramb and rejects recent attempts to redraw that chronology and to detect 'gender polarity'. Two shorter sections treat the comic presentation of musicians like Socrates' music teacher Connus (pp. 95f.) and of astronomers like Meton (pp. 96-9), a longer one (pp. 99-114) discusses the comic Socrates (above all in Clouds) and similar 'sophists' (i.e. those in Eupolis' Kolakes); some pages on Euripides and his affiliation with sophists follow (pp. 114-16). A final section (starting a bit incongruously with remarks on the 'Socratic question', i.e. 'how historical is the Socrates of the Clouds?', pp. 118-20) assembles material about philosophers in Middle and New Comedy (pp. 120-9). All in all a useful survey, but it could have been more concise, and not much of the ground covered here is really new.

The second part of the book consists of 'commenti' (i.e. commentaries, with Greek text and Italian translation, on the fragments of some comic poets) on four 'minor' comic poets (three from Old and one from New Comedy). Here, Piero Totaro tackles Amipsias (pp. 133-94), Imperio, Callias (pp. 195-254), Anna Maria Belardinelli, Diodorus (the brother of Diphilus; pp. 255-89), and Matteo Pellegrino, Metagenes (pp. 291-339). Why these four? We are never told, but I assume that they were chosen because the quantity of fragments in each case made a treatment in 35-60 pages possible. Each of the commentators has taken great pains to do his job; still, it must be said that their efforts do not significantly advance our knowledge about the plays these fragments once belonged to, beyond what we already knew from PCG. The 'commenti' are strongest in elucidating the realia mentioned in the fragments, often nearly smothering the reader with a wealth of detail. Do we really need more than a page's documentation that the Greek loved to make spirited conversation at symposia (pp. 295f.), or two pages (pp. 226-8) on the meanings of $\sigma \epsilon \mu \nu$ ós? Sometimes this leads to the really significant parallels being simply drowned in a welter of material that is only distantly related to the phenomenon in question (see e.g. the treatment on culinary metaphor in comedy on pp. 329f.). There are still other features which squander space: as a result of, apparently, too little internal coordination between the contributors, we get repeated treatments of the same matter (e.g. the mixing of wine and water on pp. 146f. and 261f., the pay for prostitutes on pp. 258 and 301f.), when one (with short cross-references at the other places) would have been enough. As there is no general bibliography, we get the same longish titles of articles and books (often a non-Italian original together with its Italian translation) taking up several lines several times. In apparently taking length of treatment as a worth in itself, these 'commenti' look like emulators of Arnott's Alexis which in many places might have profited, too, from being less prolix (see H. Lloyd-Jones, ClJ 93 [1997], 207 and my own review, forthcoming in Gnomon).

Unfortunately, the 'commenti' sometimes get things wrong which are right in PCG: discussing the attribution of the 'Grammatical tragedy' to Callias on p. 197, I. 
mistakenly takes Kassel-Austin's (PCG 4.40) statement 'de comico actum est' (which, of course, means 'it is all over with . ..') to mean 'che fosse comunque opera di un commediografo ... a a parere di Kassel et Austin'. On p. 198 (n. 8) she scolds the $P C G$ editors because they present ' $E_{\nu \tau] \epsilon \rho \alpha} \sigma \iota \delta \eta \rho \hat{\alpha}(P C G$ 4.42) and ' $Y \pi] \epsilon \rho \alpha \quad \sigma \iota \delta \eta \rho \hat{\alpha}$ (ibid. p. 49) 'come titoli di due distinte commedie'; Kassel and Austin, of course, do no such thing, but simply exhibit both titles, because both are possible. Equally unjustified seems her criticism (p. 250, on Call. fr. 35) of Kassel-Austin's (in PCG 7.140) comparison of $\epsilon \lambda \lambda \epsilon \beta o \rho \iota \hat{\alpha} \nu$ and $\dot{v} \sigma \kappa \kappa v \alpha \mu \hat{\alpha} \nu$ for the meaning of 'being mad'; the two verbs simply approach the same meaning from a different angle. Other flaws: on p. 217,

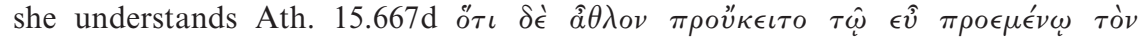
кó $\tau \tau \alpha \beta o v$ ('that a prize was set for skilfully tossing the cottabos . . .') as 'siamo informati che il termine кó $\tau \alpha \beta$ os designava . . . anche i premi assegnati ai vincitori'.

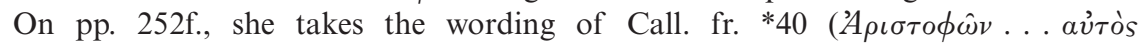

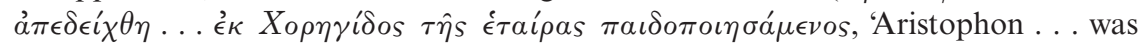
himself shown . . . to have had children by the hetaira Choregis') to mean 'Aristofonte ... fu attaccato ... . per essere egli stesso figlio di' un etera, di nome Coregis'. According to her, the idea that in fr. 15 a personification of Tragedy is present originates with Italo Gallo (p. 223); Kassel and Austin inform us that this was already proposed by Gottfried Hermann. On p. 242 (on Call. fr. 25) she cites Kühn's superannuated edition of Galen, while Kassel and Austin had already provided a more recent and better one. B. (on pp. 265f. n. 12) discusses the relationship of Menander's

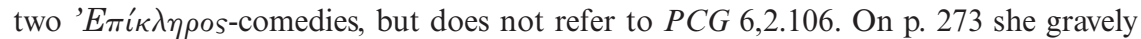
misrepresents my opinion (in Lukians Parasitendialog, p. 55), stating 'a parere di Nesselrath, modello del dialogo lucianeo non sarà la commedia, bensí la retorica, e in particolare Aristide'; what I really say is that one particular feature of Lucian's parasite derives not from comedy, but from rhetoric, and I refer not to Aristides, but to Pseudo-Aristides; nor do I say (Parasitendialog, p. 110) that Chaereas in Menander's Dyskolos is not a parasite (as B. hints on p. 278), but one with not very distinctive traits. On p. 282 she confuses Attic demes with phylai; on p. 283 she ascribes a Menander fragment to Kassel-Austin ('Theophoroumene ... fr. 1 K.-A.') which they have not yet

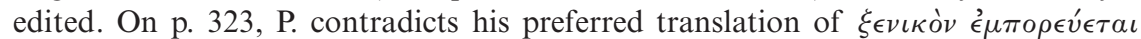
('traffica con truppe mercenarie') of Metag. fr. $10.3 \mathrm{~K} .-\mathrm{A}$. by explaining that this expression 'risulterebbe un richiamo all'accusa di $\xi \in v^{\prime} \alpha$ ' (p. 324), which cannot affect a man who only deals with foreign troops.

At times the rate of misprints is rather high; especially annoying are quotations distorted by omitted words or phrases (see Ar. Nub. 333 on p. 75; Philem. fr. 78.4-7 K.-A. on p. 75 n. 56; Ar. Nub. 969c-972 on p. 94; Cratin. fr. 167 K.-A. on p. 104 n. 115 ; Cratin. II fr. 7.3-5 K.-A. on p. 123; Ath. 4.140e on p. 209; Ath. 4.177a on p. 240; Ar. Ran. 1280 on p. 247; Nicostr. fr. 38 K.-A. on p. 251). Apart from a general bibliography (see above) I also missed a list of the many abbreviations which all contributors use extensively; not all readers will have acronyms like DAGR, DELG, DGE, GEW, LS, LSA, and others at their fingertips. The index section (provided by Mario Adreassi and Anna Tiziana Drago) is very uneven: there is a rather full 'Indice degli autori moderni' (pp. 343-54) and an ever fuller 'Indice dei passi citati' (pp. 355-75), but the 'Indice dei nomi e delle cose notevoli' (pp. 377-80) and the 'Indice dei termini greci' (p. 381) are much too short and therefore insufficient; I could easily fill another page by just listing the (in my view) necessary additions I pencilled in.

All in all, the book has its uses, but it is marred by editorial infelicities and by avoidable mistakes; I hesitate to call it an indispensable tool for working with Greek comic fragments. 


\section{LYRIC REFLEX}

\section{Kugelmeier: Reflexe früher und zeitgenössischer Lyrik in der} Alten attischen Komödie. (Beiträge zur Altertumskunde, 80.) Pp. 379. Stuttgart and Leipzig: B. G. Teubner, 1996. Cased, DM 136. ISBN: 3-519-07629-2.

This revised version of a Cologne dissertation examines the various ways in which reflections of lyric poetry are found in Old Comedy. Lyric is understood to embrace choral lyric, monody, elegy, iambus, and dithyramb, here referred to in the term 'zeitgenössische Lyrik'; comedy, for the most part, naturally means Aristophanes, but room is also found for what we know of other poets.

In his largely programmatic introduction Kugelmeier explains the term 'Reflex', stressing that it is not confined to instances of parody, but covers the whole range of comedy's exploitation of lyric themes, wording, and rhythm. While particular instances of lyric Reflex have been treated elsewhere, this book aims to provide a comprehensive and systematic study of the topic. $\mathrm{K}$. is aware that allusion is difficult to detect and his own procedure is judiciously cautious and distinguishes between verbatim quotation, reference, reminiscence, and more general allusion to an author and his work. An important feature of his investigation is to show how lyric allusion is embedded in a variety of structural contexts and that the effect of the allusion is by no means confined to the comic or even humorous.

$\mathrm{K}$. has fulfilled his aim and I found this a useful book which brings together a great deal of material and discusses key problems of text and interpretation in a balanced way. It was not easy reading, since the marks of the dissertation are still there, especially in the mass of detail on peripheral issues.

K.'s opening discussion on the tradition of lyric in the texts of comedy begins with a consideration of the evidence for literacy and a Buchkultur. He comes to the conclusion that, while an oral tradition was retained, written texts were in wide circulation by the end of the fifth century. The evidence is ambiguous, but even if it points to a widespread basic literacy, this needs to be distinguished from a general facility in reading literary texts. In any case, $\mathrm{K}$. exaggerates the degree of knowledge on which the effect of a literary joke in the theatre depends.

In his discussion of the form in which lyric texts are transmitted in comedy $\mathrm{K}$. takes a number of passages illustrating divergent traditions in terms of phonology, vocabulary, and attribution. His discussion raises interesting issues about the relationship between the comic text, the original form of the words it quotes or recalls (often restored by later grammarians), and the form in which the lyric was generally circulating. The comic text can be an index, K. rightly points out, of the normalization of dialectal forms (in conformity with either Attic forms or those of the Kunstsprache of dramatic lyric); it can also reflect a generally held, if wrong, view of authorship (cf. Frogs 659, which belongs not to Hipponax but to Ananios).

Before turning to the symposium, the principal occasion for the performance of all kinds of lyric poetry, K. discusses two passages, Peace 1295ff. and Clouds 966ff., in respect of the education of the young. In each case his inferences seem to me too literal: the skills of the lads are manufactured to illustrate comically the passionate attachments of the older men. The bulk of the symposium discussion focuses on the 